\title{
FAKTOR-FAKTOR YANG BERHUBUNGAN DENGAN KEJADIAN GASTRITIS PADA PASIEN YANG BEROBAT DI PUSKESMAS
}

\author{
MUHAMMAD SYAFI' $I^{1}$, DINA ANDRIANI ${ }^{2}$ \\ 1,2 SEKOLAH TINGGI ILMU KESEHATAN NURUL HASANAH \\ Jl. Ahmad Yani, Pulo Kemiri Kecamatan Babussalam \\ Kutacane, Kabupaten Aceh Tenggara Provinsi Aceh \\ Email : syafiijulio@gmail.com
}

DOI : https://doi.org/10.35451/jkf.v2i1.281

\begin{abstract}
Gastritis is a health problem that is still very common in the community. gastritis is an inflammation or bleeding in the gastric mucosa caused by irritation, infection, and irregularities in eating patterns. Based on observations at the Lak-Lak Public Health Center in Ketambe Sub-District, Southeast Aceh Regency, the number of gastritis sufferers in January to March 2019 totaled 128 people and to date the factors associated with the incidence of gastritis in this region are not yet clearly known. This study aims to determine the factors associated with gastritis in patients seeking treatment at the Lak-Lak Public Health Center in Ketambe District, Southeast Aceh Regency in 2019. This study used a cross sectional approach. The results of the study using the Chisquare test based on factors of eating habits and coffee drinking habits are factors associated with gastritis because of the $p$-value of $\leq 0,05$. While smoking habits, alcohol consumption habits and stress are factors that are not related to gastritis due to the $p$-value $\geq 0,05$.
\end{abstract}

Keywords : Eating Habits, Coffee Drinking habits, Smoking Habits, Alcohol Consumption Habits, Stress.

\section{PENDAhULUAN}

Kesehatan merupakan salah satu faktor yang harus diperhatikan oleh setiap makhluk hidup khususnya manusia. Kesehatan mencakup keadaan fisik, mental, dan sosial sehingga setiap orang yang sehat akan memungkinkan hidup produktif secara sosial dan ekonomi. Kesehatan menjadi hal yang sangat perlu diperhatikan khususnya pada anak-anak, remaja, maupun orang tua. Sebab, apabila seseorang tidak menjaga kesehatan maka akan menurunkan produktivitas dan bahkan dapat meningkatkan angka kematian (Benita, 2012).

Menurut Arikah dan Muniroh (2015), dalam lingkungan masyarakat tidak jarang ditemukan seseorang mengalami penurunan produktivitas, keadaan tersebut tentunya dialami oleh orang yang menderita sakit. Salah satu penyakit yang sangat sangat lazim ditemukan di lingkungan masyarakat yaitu penyakit gastritis. gastritis merupakan salah satu gangguan pencernaan akibat pola makan, dan hampir 10 persen penduduk dunia menderita gastritis.

Gastritis merupakan masalah kesehatan yang masih sangat banyak ditemukan di lingkungan masyarakat (Putri dkk, 2010). Penyakit gastritis biasa dikenal dengan penyakit maag. gastritis ini merupakan suatu peradangan atau pendarahan pada 
Received: 02 Oktober 2019 :: Accepted: 08 Oktober 2019:: Published: 31 Oktober 2019

mukosa lambung yang disebabkan oleh faktor iritasi, infeksi, dan ketidakteraturan dalam pola makan, misalnya telat makan, makan terlalu banyak, makan cepat, makan makanan yang terlalu banyak bumbu pedas, mengkonsumsi protein tinggi, kebiasaan mengkonsumsi makan-makanan pedas, dan minum kopi terlalu berlebihan (Huzaifah, 2017).

Gastritis termasuk proses inflamasi atau gangguan kesehatan yang disebabkan oleh faktor iritasi dan infeksi pada mukosa dan submukosa lambung. Penyakit gastritis dapat menyerang seluruh lapisan masyarakat dari semua tingkat usia maupun jenis kelamin, akan tetapi dari beberapa survei menunjukkan bahwa gastritis paling sering menyerang usia produktif (Tussakinah dkk, 2018).

Berdasarkan data dari badan penelitian kesehatan Dunia World Health Organization (WHO) yang dikutip oleh Huzaifah (2017) menemukan bahwa, beberapa negara yang mengalami angka persentase kejadian gastritis tertinggi di dunia diantaranya adalah inggris 22\%, China 31\%, Jepang $14.5 \%$, Kanada 35\%, dan Perancis $29.5 \%$.

Arikah dan Muniroh (2015) menemukan bahwa, di Indonesia angka kejadian Gastritis pada masyarakat tergolong masih sangat tinggi yaitu sebesar 40,8 persen dan angka kejadian gastritis di beberapa daerah di Indonesia masih cukup tinggi dengan angka kejadian 274.396 kasus dari 238.452.952 jiwa penduduk. Sehingga, rata-rata disetiap daerah di Indonesia persoalan yang menyangkut penyakit ini masih belum terpecahkan.

Menurut Huzaifah (2017), walaupun sampai saat ini resiko penyakit gastritis ini masih sangat tinggi dan masalahnya belum terpecahkan, namun yang terjadi di kalangan usia muda maupun masyarakat luas ternyata masih banyak yang tidak terlalu memperhatikan kesehatan dan menjaga gaya hidup terutama dari apa yang dikonsumsi, penggunaan obat-obatan, stres, infeksi bakteri, serta pola makan dan minum yang kurang baik. Untuk dapat meningkatkan derajat kesehatan masyarakat yaitu menyelenggarakan pelayanan kesehatan yang prima dan sebaiknya mendeteksi lebih awal faktorfaktor yang berhubungan dengan penyebab penyakit tersebut.

\section{METODE}

Jenis penelitian ini adalah jenis penelitian deskriptif korelasional. Penelitian ini akan dilaksanakan di Puskesmas Lak-Lak, beramat di Jalan Kutacane - Blangkejeren Desa Lak-Lak Kecamatan Ketambe Kabupaten Aceh Tenggara Provinsi Aceh. Teknik pengambilan sampel dalam penelitian ini menggunakan teknik Accidental Sampling dengan jumlah sampel dalam penelitian ini ketika dilakukannya penelitian yaitu berjumlah 35 orang.

\section{HASIL}

1). Analisis Univariat

Tabel 1. Distribusi Frekuensi Karakteristik Responden Berdasarkan Umur, Jenis Kelamin Pendidikan, dan Pekerjaan

\begin{tabular}{lcc}
\hline \multicolumn{1}{c}{$\begin{array}{c}\text { Karakteristik } \\
\text { Responden }\end{array}$} & $\mathrm{F}$ & $\%$ \\
\hline Umur & & \\
$17-26$ & 9 & 25,7 \\
$27-36$ & 13 & 37,1 \\
$37-46$ & 8 & 22,9 \\
$47-56$ & 5 & 14,3 \\
Total & 35 & 100 \\
Jenis Kelamin & & \\
Laki-Laki & 11 & 31,4 \\
Perempuan & 24 & 68,6 \\
Total & 35 & 100 \\
Pendidikan & & \\
SD & 4 & 11,4 \\
SMP & 8 & 22,9 \\
\hline
\end{tabular}


Received: 02 Oktober 2019 :: Accepted: 08 Oktober 2019:: Published: 31 Oktober 2019

\begin{tabular}{lcc}
\hline SMA & 14 & 40,0 \\
Perguruan Tinggi & 9 & 25,7 \\
Total & 35 & 100 \\
Pekerjaan & & \\
Petani & 24 & 68,6 \\
PNS & 7 & 20,0 \\
Pelajar/Mahasiswa & 4 & 11,4 \\
\hline Total & 35 & 100 \\
\hline
\end{tabular}

Berdasarkan tabel 1. diatas dapat dilihat bahwa responden berusia 17-26 tahun berjumlah 9 orang $(25,7 \%)$, usia 27-36 tahun berjumlah 13 orang (37.1 $\%)$, usia 37-46 tahun berjumlah 8 orang (22.9\%), dan berusia 47-56 tahun berjumlah 5 orang (14.3\%). Berdasarkan jenis kelamin, laki-laki berjumlah 11 orang $(3.4 \%)$ dan perempuan berjumlah 24 orang (68.6 $\%)$. Berdasarkan pendidikan, responden yang berpendidikan SD berjumlah 4 orang $(11.4 \%)$, SMP berjumlah 8 orang (22.9\%), SMA berjumlah 14 orang (40 $\%$ ) dan Perguruan tinggi berjumlah 9 orang (25.7 \%), dan berdasarkan pekerjaan, responden bekerja sebagai petani berjumlah 24 orang $(68.6 \%)$, PNS berjumlah 7 orang (20\%), dan pelajar/mahasiswa berjumlah 4 orang (11.4\%).

Tabel 2. Distribusi Frekuensi Responden Berdasarkan Kebiasaan Makan

\begin{tabular}{lcc}
\hline $\begin{array}{c}\text { Kebiasaan } \\
\text { Makan }\end{array}$ & $\mathrm{f}$ & $\%$ \\
\hline Baik & 7 & 20 \\
Tidak Baik & 28 & 80 \\
\hline Total & 35 & 100 \\
\hline
\end{tabular}

Berdasarkan tabel 2. diatas dapat dilihat bahwa, berdasarkan kebiasaan makan pada kategori tidak baik berjumlah 28 orang $(80 \%)$ sementara kategori baik berjumlah 7 orang (20 $\%)$.

Tabel 3. Distribusi Frekuensi Responden Berdasarkan Kebiasaan Merokok

\begin{tabular}{lcc}
\hline Kebiasaan Merokok & $\mathrm{f}$ & $\%$ \\
\hline Merokok & 8 & 22,9 \\
Tidak Merokok & 27 & 77,1 \\
\hline
\end{tabular}

\begin{tabular}{lll}
\hline Total & 35 & 100 \\
\hline
\end{tabular}

Berdasarkan tabel 3 diatas dapat dilihat bahwa, frekuensi responden yang tidak memiliki kebiasaan merokok adalah berjumlah 27 orang (77.1 \%) sementara frekuensi responden yang memiliki kebiasaan merokok adalah berjumlah 8 orang (22.9\%).

Tabel 4. Distribusi Frekuensi Responden Berdasarkan Kebiasaan Konsumsi Alkohol

\begin{tabular}{lcc}
\hline $\begin{array}{c}\text { Kebiasaan } \\
\text { Mengkonsumsi } \\
\text { Alkohol }\end{array}$ & $\mathrm{F}$ & $\%$ \\
\hline $\begin{array}{l}\text { Mengkonsumsi } \\
\begin{array}{l}\text { Alkohol } \\
\text { Tidak }\end{array}\end{array}$ & 1 & 2,9 \\
$\begin{array}{l}\text { Mengkonsumsi } \\
\text { Alkohol }\end{array}$ & 34 & 97,1 \\
\hline Total & 35 & 100 \\
\hline
\end{tabular}

Berdasarkan tabel 4. diatas dapat dilihat bahwa, frekuensi responden yang tidak memiliki kebiasaan mengkonsumsi alkohol adalah berjumlah 34 orang $(97,1 \%)$ dan frekuensi responden yang memiliki kebiasaan mengkonsumsi alkohol adalah berjumlah 1 orang $(2,9$ $\%)$.

Tabel 5. Distribusi Frekuensi Responden Berdasarkan Kebiasaan Minum Kopi

\begin{tabular}{lcc}
\hline $\begin{array}{l}\text { Kebiasaan } \\
\text { Minum Kopi }\end{array}$ & $\mathrm{f}$ & $\%$ \\
\hline $\begin{array}{l}\text { Minum } \\
\text { Kopi } \\
\text { Tidak }\end{array}$ & 20 & 57,1 \\
$\begin{array}{l}\text { Minum } \\
\text { Kopi }\end{array}$ & 15 & 42,9 \\
\hline Total & 35 & 100 \\
\hline
\end{tabular}

Berdasarkan tabel 5. dapat dilihat bahwa, frekuensi responden yang tidak memiliki kebiasaan minum kopi adalah berjumlah 20 orang $(57,1 \%)$ dan frekuensi responden yang memiliki kebiasaan tidak minum kopi adalah berjumlah 15 orang (42,9\%).

Tabel 6. Distribusi Frekuensi Responden Berdasarkan Stres 
Received: 02 Oktober 2019 :: Accepted: 08 Oktober 2019:: Published: 31 Oktober 2019

\begin{tabular}{|c|c|c|}
\hline Stres & $\mathrm{f}$ & $\%$ \\
\hline Stres & 21 & 60,0 \\
\hline Tidak & 14 & 40,0 \\
\hline \multicolumn{3}{|l|}{ Stres } \\
\hline Total & 35 & 100 \\
\hline
\end{tabular}

dilihat bahwa, frekuensi responden yang tidak mengalami stres adalah berjumlah 21 orang $(60 \%)$ sementara frekuensi responden yang mengalami tidak stres adalah berjumlah 14 orang (40\%).

\section{2). Analisis Bivariat}

Tabel 7. Hubungan Kebiasaan Makan Dengan Kejadian Gastritis Pada Pasein Yang Berobat Di Puskesmas

\begin{tabular}{|c|c|c|c|c|c|c|}
\hline \multirow{3}{*}{$\begin{array}{c}\text { Kebiasaan } \\
\text { Makan }\end{array}$} & \multicolumn{4}{|c|}{ Kejadian Gastritis } & \multirow{3}{*}{$\begin{array}{c}\text { Total } \\
\%\end{array}$} & \multirow{3}{*}{$\begin{array}{c}\text { Person } \\
\text { Chi-Square }\end{array}$} \\
\hline & \multicolumn{2}{|c|}{ Berisiko } & \multicolumn{2}{|c|}{$\begin{array}{c}\text { Tidak } \\
\text { Berisiko }\end{array}$} & & \\
\hline & $f$ & $\%$ & $\mathrm{f}$ & $\%$ & & \\
\hline Baik & 5 & 15,6 & 2 & 66,7 & 20 & 0,035 \\
\hline Tidak Baik & 27 & 84,4 & 1 & 33,3 & 80 & \\
\hline Total & 32 & 100 & 3 & 100 & 100 & \\
\hline
\end{tabular}

Berdasarkan tabel 7. di atas dapat diketahui bahwa respoden yang memiliki kebiasaan makan baik, beresiko mengalami kejadian gastritis sebanyak 5 responden $(15,6 \%)$, sedangkan responden yang memiliki kebiasaan makan tidak baik, berisiko mengalami kejadian gastritis sebanyak 27 responden $(84,4 \%)$. Sementara responden yang memiliki kebiasaan makan baik, tidak berisiko mengalami kejadian gastritis sebanyak 2 responden $(66,7 \%)$ sedangkan responden yang memiliki kebiasaan makan tidak baik, tidak berisiko mengalami kejadian gastritis sebanyak 1 responden $(33,3$ $\%)$. Berdasarkan hasil penghitungan didapatkan nilai person chi-square sig. sebesar 0.036 . Artinya adalah nilai yang diperoleh tersebut lebih kecil dari 0,05 $(p<0,05)$. Jadi, dari hasil penelitian tersebut maka dapat ditarik kesimpulan bahwa kebiasaan minum kopi berhubungan dengan kejadian gastritis di Puskesmas.
Tabel 8. Hubungan Kebiasaan Merokok Dengan Kejadian Gastritis Pada Pasein Yang Berobat Di Puskesmas

Berdasarkan tabel 8. dapat diketahui bahwa responden yang tidak memiliki kebiasaan merokok, beresiko

\begin{tabular}{|c|c|c|c|c|c|c|c|}
\hline \multirow{3}{*}{$\begin{array}{l}\text { Kebiasaan } \\
\text { Merokok }\end{array}$} & \multicolumn{4}{|c|}{ Kejadian Gastritis } & \multirow{2}{*}{\multicolumn{2}{|c|}{$\begin{array}{c}\text { Total } \\
\%\end{array}$}} & \multirow{3}{*}{$\begin{array}{c}\text { Person } \\
\text { Chi-Square }\end{array}$} \\
\hline & \multicolumn{2}{|c|}{ Berisiko } & \multicolumn{2}{|c|}{$\begin{array}{c}\text { Tidak } \\
\text { Berisiko }\end{array}$} & & & \\
\hline & $f$ & $\%$ & $f$ & $\%$ & f & $\%$ & \\
\hline $\begin{array}{l}\text { Tidak } \\
\text { Merokok. }\end{array}$ & 25 & 78,1 & 2 & 66,7 & 27 & 77,1 & 0,651 \\
\hline Merokak & 7 & 21,9 & 1 & 33,3 & 8 & 22,9 & \\
\hline Total & 32 & 100 & 3 & 100 & 35 & 100 & \\
\hline
\end{tabular}

mengalami kejadian gastritis sebanyak 25 responden $(78,1 \%)$, sedangkan responden yang memiliki kebiasaan merokok, beresiko mengalami kejadian gastritis sebanyak 7 responden $(21,9$ $\%)$. Sementara respoden yang tidak memiliki kebiasaan merokok, tidak beresiko mengalami kejadian gastritis sebanyak 2 responden $(66,7 \%)$ sedangkan responden yang memiliki kebiasaan merokok, tidak beresiko mengalami kejadian gastritis sebanyak 1 responden (33,3\%). Jadi, dapat diketahui bahwa paling responden yang tidak memiliki kebiasaan merokok beresiko mengalami kejadian gastritis yaitu sebanyak 25 responden (78,1\%). Berdasarkan hasil penghitungan didapatkan nilai Person Chi-Square sig. sebesar $p=0,651$. Artinya adalah nilai $p$ value lebih besar dari $0.05(p>0,05)$. Jadi, dari hasil penelitian tersebut maka dapat ditarik kesimpulan bahwa kebiasaan merokok tidak berhubungan dengan kejadian gastritis di Puskesmas.

Tabel 9. Hubungan Kebiasaan Konsumsi Alkohol Dengan Kejadian

\begin{tabular}{|c|c|c|c|c|c|c|c|}
\hline \multirow{3}{*}{$\begin{array}{c}\text { Kebiasaan } \\
\text { Konsumsi } \\
\text { Alkohol }\end{array}$} & \multicolumn{4}{|c|}{ Kejadian Gastritis } & \multirow{2}{*}{\multicolumn{2}{|c|}{ Total }} & \multirow{3}{*}{$P C$} \\
\hline & \multicolumn{2}{|c|}{ Beresiko } & \multicolumn{2}{|c|}{$\begin{array}{c}\text { Tidak } \\
\text { Beresiko }\end{array}$} & & & \\
\hline & f & $\%$ & $f$ & $\%$ & $f$ & $\%$ & \\
\hline Tidak & & & & & & & \\
\hline $\begin{array}{c}\text { konsumsi } \\
\text { alkohol }\end{array}$ & 31 & $96.9 \%$ & 3 & $100 \%$ & 34 & $97.1 \%$ & 0.756 \\
\hline $\begin{array}{c}\text { Konsumsi } \\
\text { alkohol }\end{array}$ & 1 & $3.1 \%$ & 0 & $0 \%$ & 1 & $2.9 \%$ & \\
\hline Total & 32 & 100 & 3 & 100 & 35 & 100 & \\
\hline
\end{tabular}


Received: 02 Oktober 2019 :: Accepted: 08 Oktober 2019:: Published: 31 Oktober 2019

Gastritis Pada Pasein Yang Berobat Di Puskesmas

Berdasarkan tabel 9. dapat diketahui bahwa responden yang tidak memiliki kebiasaan konsumsi alkohol, beresiko mengalami kejadian gastritis sebanyak 31 responden (96,9\%), sedangkan responden yang memiliki kebiasaan konsumsi alkohol, beresiko mengalami kejadian gastritis hanya sebanyak 1 responden $(3,1 \quad \%)$. Sementara respoden yang tidak memiliki kebiasaan konsumsi alkohol, tidak beresiko mengalami kejadian gastritis sebanyak 3 responden (100\%), sedangkan responden yang tidak memiliki kebiasaan konsumsi alkohol, tidak ada beresiko mengalami kejadian gastritis sebanyak 1 responden (33,3\%). Jadi, dapat diketahui bahwa paling banyak responden tidak memiliki kebiasaan mengkonsumsi alkohol beresiko mengalami kejadian gastritis yaitu berjumlah 31 responden (96,9 \%). Berdasarkan hasil penghitungan didapatkan nilai person chi-square sig. sebesar 0.756 . Artinya adalah nilai yang diperoleh tersebut lebih besar dari 0.05 $(p>0.05)$. Jadi, dari hasil penelitian tersebut maka dapat ditarik kesimpulan bahwa kebiasaan konsumsi alkohol tidak berhubungan dengan kejadian gastritis di Puskesmas.

Tabel 10. Hubungan Kebiasaan Minum Kopi Dengan Kejadian Gastritis Pada Pasein Yang Berobat Di Puskesmas

\begin{tabular}{|c|c|c|c|c|c|c|c|}
\hline \multirow{3}{*}{$\begin{array}{c}\text { Kebiasaan } \\
\text { Minuma } \\
\text { Kopi }\end{array}$} & \multicolumn{4}{|c|}{ Kejadian Gastritis } & \multirow{2}{*}{\multicolumn{2}{|c|}{$\begin{array}{c}\text { Total } \\
\%\end{array}$}} & \multirow{3}{*}{$\begin{array}{c}\text { Person } \\
\text { Chi-Square }\end{array}$} \\
\hline & \multicolumn{2}{|c|}{ Berisiko } & \multicolumn{2}{|c|}{$\begin{array}{c}\text { Tidak } \\
\text { Berisiko }\end{array}$} & & & \\
\hline & $f$ & $\%$ & $f$ & $\%$ & $f$ & $\%$ & \\
\hline $\begin{array}{l}\text { Minum } \\
\text { Kopi }\end{array}$ & 20 & 62,5 & - & - & 20 & 57,1 & \\
\hline $\begin{array}{l}\text { Tidak } \\
\text { Minum } \\
\text { Kopi } \\
\end{array}$ & 12 & 37,5 & 3 & 100 & 15 & 42,9 & 0,036 \\
\hline Total & 32 & 100 & 3 & 100 & 35 & & \\
\hline
\end{tabular}

Berdasarkan tabel 10. di atas dapat diketahui bahwa responden yang memiliki kebiasaan minum kopi, beresiko mengalami kejadian gastritis sebanyak 20 responden $(62,5 \%)$, sedangkan responden yang tidak memiliki kebiasaan minum kopi, beresiko mengalami kejadian gastritis sebanyak 12 responden (37.5 \%). Sementara respoden yang memiliki kebiasaan tidak minum kopi, tidak beresiko mengalami kejadian gastritis sebanyak 3 responden (100 \%). Jadi, dapat diketahui bahwa paling banyak responden memiliki kebiasaan minum kopi beresiko mengalami kejadian gastritis yaitu berjumlah 20 responden $(62,5 \%)$. Berdasarkan hasil penghitungan didapatkan nilai person chi-square sig. sebesar 0.036 . Artinya adalah nilai yang diperoleh tersebut lebih kecil dari $0.05(p<0.05)$. Jadi, dari hasil penelitian tersebut maka dapat ditarik kesimpulan bahwa kebiasaan minum kopi berhubungan dengan kejadian gastritis di Puskesmas.

Tabel 11. Hubungan Stres Dengan Kejadian Gastritis Pada Pasein Yang Berobat Di Puskesmas

\begin{tabular}{|c|c|c|c|c|c|c|c|}
\hline \multirow{3}{*}{ Stres. } & \multicolumn{4}{|c|}{ Kejadian Gastritis } & \multirow{2}{*}{\multicolumn{2}{|c|}{$\begin{array}{c}\text { Total } \\
\%\end{array}$}} & \multirow{3}{*}{$\begin{array}{c}\text { Person } \\
\text { Chi-Square }\end{array}$} \\
\hline & \multicolumn{2}{|c|}{ Berisiko } & \multicolumn{2}{|c|}{$\begin{array}{c}\text { Tidak } \\
\text { Berisiko }\end{array}$} & & & \\
\hline & $f$ & $\%$ & $f$ & $\%$ & $f$ & $\%$ & \\
\hline Stres & 18 & 56,3 & 3 & 100 & 21 & 60 & \multirow{3}{*}{0,139} \\
\hline Tidak Stres. & 14 & 43,8 & - & - & 14 & 40 & \\
\hline Total & 32 & 100 & 3 & 100 & 35 & 100 & \\
\hline
\end{tabular}

Berdasarkan tabel 11. di atas dapat diketahui bahwa responden yang stres, beresiko mengalami kejadian gastritis sebanyak 18 responden (56,3\%), sedangkan responden yang tidak mengalami stres, beresiko mengalami kejadian gastritis sebanyak 14 responden (43,8 \%). Sementara respoden yang stres, tidak beresiko mengalami kejadian gastritis sebanyak 3 responden (100\%). Jadi, dapat diketahui bahwa paling banyak responden stres beresiko mengalami kejadian gastritis yaitu berjumlah 18 responden $(56,3 \%)$. Berdasarkan hasil 
Received: 02 Oktober 2019 :: Accepted: 08 Oktober 2019:: Published: 31 Oktober 2019

penghitungan didapatkan nilai person chi-square sig. sebesar 0,139. Artinya adalah nilai yang diperoleh tersebut lebih besar dari 0,05 $(p>0,05)$. Jadi, dari hasil penelitian tersebut maka dapat ditarik kesimpulan bahwa tidak ada hubungan stres dengan kejadian gastritis pada pasien yang berobat di Puskesmas.

\section{PEMBahasan}

1) Hubungan Kebiasaan Makan Dengan Kejadian Gastritis Pada Pasien Yang Berobat Di Puskesmas

Hasil uji hipotesis dengan menggunakan uji chi-square $\left(x^{2}\right)$ pada kemaknaan $95 \% \quad(a \quad 0,05)$ dengan bantuan SPSS, diperoleh nilai $p=0.035$. Pengujian ini dapat dilihat bahwa nilai $p$ $(0.035)$ yang diperoleh lebih kecil dari $a$ $(0,05)$. Jadi, ini berarti bahwa ada hubungan kebiasaan makan dengan kejadian gastritis di Puskesmas Lak-Lak Kecamatan Ketambe Kabupaten Aceh Tenggara Tahun 2019. Hasil penelitian ini menunjukkan bahwa adanya kemiripan dengan penelitian yang dilakukan sebelumnya di wilayah kerja Puskesmas Tarok kota Payakumbuh tahun 2017 oleh Tussakinah dkk (2018), dimana didapat suatu kesimpulan terdapatnya hubungan antara pola makan dengan kekambuhan gastritis.

Hasil penelitian ini mengingatkan bahwa setiap orang harus menjaga kebiasaan makan sesuai dengan yang dianjurkan. Dimana, membiasakan makan secara teratur setiap waktunya, mengurangi mengkonsumsi jenis-jenis makanan pedas dan menghindari minuman yang bersoda. Apabila faktor kebiasaan makan telah dijaga sesuai dengan waktunya maka kejadian gastritis akan dapat terhindari sehingga kualitas kesehatan akan meningkat pula. Menurut Megawati dan Nosi (2014), kebiasaan makan terbagi dalam 3 waktu yaitu sarapan pagi, makan siang dan makan malam. Ketiga waktu makan makan tersebut tidak boleh diabaikan karena makanan menentukan kerja tubuh setiap hari.

2) Hubungan Kebiasaan Merokok Dengan Kejadian Gastritis Pada Pasien Yang Berobat Di Puskesmas

Analisis bivariat tentang hubungan kebiasaan merokok dengan kejadian gastritis di Puskesmas Lak-Lak Kecamatan Ketambe Kabupaten Aceh Tenggara Tahun 2019 dari 35 orang pasien yang mengalami kejadian gastritis, ternyata mayoritas dari mereka tidak mempunyai kebiasaan merokok yaitu berjumlah 25 orang. Hasil uji hipotesis dengan menggunakan uji chi-square $\left(x^{2}\right)$ pada kemaknaan 95\% (a 0,05) dengan bantuan SPSS, diperoleh nilai $p=0,651$. Pengujian ini dapat dilihat bahwa nilai $p(0,651)$ yang diperoleh lebih besar dari $a(0,05)$. Jadi, ini berarti bahwa tidak ada hubungan kebiasaan merokok dengan kejadian gastritis di Puskesmas Lak-Lak Kecamatan Ketambe Kabupaten Aceh Tenggara Tahun 2019. Hasil penelitian ini sejalan dengan hasl penelitian yang dilakukan oleh Lumiwu dkk (2015) dimana, hasil uji statistik menggunakan uji-chi square diperoleh nilai probabilitas ( $p$ value) sebesar 0,614 . Angka ini lebih besar dari 0,05. Sehingga dapat dinyatakan bahwa tidak terdapat hubungan antara merokok dengan kejadian gastritis.

Kebiasaan merokok merupakan bukan faktor yang berhubungan kejadian gastritis di wilayah di Puskesmas Lak-Lak Kecamatan Ketambe Kabupaten Aceh Tenggara karena reponden pada penelitian ini mayoritas berjenis kelamin perempun dan tidak merokok. Walaupun kebiasaan merokok bukan salah satu factor yang berhubungan dengan kejadian gastritis di lokasi penelitian ini, namun merokok juga tentunya secara tidak langsung sangat berdampak terhadap kejadian 
Received: 02 Oktober 2019 :: Accepted: 08 Oktober 2019:: Published: 31 Oktober 2019

gastritis. Menurut Rukmana (2018), dalam gaya hidup merokok ternyata secara tidak langsung dapat merangsang produksi asam lambung secara berlebihan dan penurunan daya tahan tubuh juga. Oleh karena itu, untuk menghindari kejadian gastritis dan penyakit lainnya maka konsumsi rokok juga harus diatur dan dikurangi.

3) Hubungan Kebiasaan Konsumsi Alkohol Dengan Kejadian Gastritis Pada Pasien yang Berobat Di Puskesmas

Analisis bivariat tentang hubungan kebiasaan konsumsi alkohol dengan kejadian gastritis di Puskesmas Lak-Lak Kecamatan Ketambe Kabupaten Aceh Tenggara Tahun 2019, dari 35 orang pasien yang mengalami kejadian gastritis ternyata mayoritas dari mereka tidak mempunyai kebiasaan konsumsi alkohol yaitu berjumlah 31 orang. Hasil uji hipotesis dengan menggunakan uji chi-square $\left(x^{2}\right)$ pada kemaknaan 95\% (a 0,05) dengan bantuan SPSS, diperoleh nilai $p=0,756$. Pengujian ini dapat dilihat bahwa nilai $p(0,756)$ yang diperoleh lebih besar dari $a(0,05)$. Jadi, ini berarti bahwa tidak ada hubungan kebiasaan konsumsi alkohol dengan kejadian gastritis di Puskesmas Lak-Lak Kecamatan Ketambe Kabupaten Aceh Tenggara Tahun 2019.

Hasil penelitian tersebut di atas ternyata bertolak belakang dengan pendapat Misnadiarly (2009) dalam Rukmana (2018), yang bahwa salah satu faktor yang menyebabkan seseorang mengalami kejadian diare yaitu karena mengkonsumsi alkohol yang berlebihan. Sementara tidak adanya hubungan kebiasaan konsumsi alkohol dengan kejadian gastritis dilokasi penelitian ini karena responden penelitian rata-rata tidak mengkonsumsi alkohol. Namun demikian, seseorang yang mengkonsumsi alkohol sangat rentan terhadap kejadian gastritis karena konsumsi alkohol yang berlebihan akan menyebabkan gangguan pada lambung dan saluran pencernaan lainnya. Menurut Brunner dan Sudarth (2006) dalam Rukmana (2018), mengkonsumsi alkohol yang berlebihan dapat menyebabkan peradangan mukosa lambung. Disamping itu, menurut Rukmana (2018), dalam gaya hidup mengkonsumsi alkohol akan merangsang produksi asam lambung secara berlebihan dan penurunan daya tahan tubuh. Oleh karena itu, untuk menghindari resiko kejadian gastritis dan terciptanya derajad kesehatan yang lebih baik maka minuman jenis alkohol harus dihindari.

4) Hubungan Kebiasaan Minum Kopi Dengan Kejadian Gastritis Pada Pasien Yang Berobat Di Puskesmas Hasil uji hipotesis dengan menggunakan uji chi-square $\left(x^{2}\right)$ pada kemaknaan $95 \% \quad(a \quad 0,05)$ dengan bantuan SPSS, diperoleh nilai $p=0,036$. Pengujian ini dapat dilihat bahwa nilai $p$ $(0,036)$ yang diperoleh lebih kecil dari $a$ $(0,05)$. Jadi, ini berarti bahwa ada hubungan antara kebiasaan minum kopi dengan kejadian gastritis di Puskesmas Lak-Lak Kecamatan Ketambe Kabupaten Aceh Tenggara Tahun 2019. Artinya adalah seseorang yang tidak minum kopi ternyata sangat banyak mengalami kejadian gastritis.

Hasil penelitian diatas ini sejalan dengan hasil penelitian yang dilakukan oleh Lumiwu dkk (2015), melalui uji statistik dengan menggunakan uji chisquare untuk menganalisis hubungan antara konsumsi kopi dengan kejadian gastritis menghasilkan nilai probabilitas ( $p$ value) sebesar 0,001. Dari angka tersebut dapat dinyatakan bahwa adanya hubungan antara konsumsi kopi dengan kejadian gastritis. yang berarti bahwa konsumsi kopi merupakan faktor risiko yang mempengaruhi kejadian 
Received: 02 Oktober 2019 :: Accepted: 08 Oktober 2019:: Published: 31 Oktober 2019

gastritis. Hasil penelitian Suarnianti (2013) dalam Lumiwu dkk (2015) yang menemukan dan menyatakan bahwa seseorang yang mengkonsumsi kopi memiliki risiko 9,609 kali lebih besar menderita gastritis dibandingkan dengan responden yang tidak mengkonsumsi kopi. Mengkonsumsi kopi yang tidak sesuai dengan ketentuan dan terlalu berlebiahan meminum kopi maka tentunya akan berdampak negatif terhadap kesehatan tubuh. Oleh karena itu, untuk menghindari kejadian gastritis, maka masyarakat yang terbiasa mgngkonsumsi kopi harus lebih memperhatikan waktu minum kopi dan berusaha membatasi komposisi kopi yang dikonsumsi.

5) Hubungan Stres Dengan Kejadian Gastritis Pada Pasien Yang Berobat Di Puskesmas

Hasil uji hipotesis dengan menggunakan uji chi-square $\left(x^{2}\right)$ pada kemaknaan $95 \%(a=0,05)$ dengan bantuan SPSS, diperoleh nilai $p=0,139$. Pengujian ini dapat dilihat bahwa nilai $p$ $(0,139)$ yang diperoleh lebih besar dari a $(0,05)$. Jadi, ini berarti bahwa tidak ada hubungan antara stres dengan kejadian gastritis di Puskesmas Lak-Lak Kecamatan Ketambe Kabupaten Aceh Tenggara Tahun 2019. Hasil penelitian ini tidak sejalan dengan hasil penelitian Rukmana (2018), nilai $p$-value diperoleh sebesar 0,021 artinya bahwa terdapat hubungan antara faktor stres dengan frekuensi kekambuhan gastritis. Disamping itu, hasil penelitian ini juga ternyata tidak sejalan dengan hasil penelitian Megawati dan Nosi (2014), yang dilakukan pada pasien yang di rawat di RSUD Labuang Baji Makassar, dari hasil uji statistik didapatkan nilai $p=0,008$. Artinya adalah faktor stres mempengaruhi kejadian gastritis.

Menurut Rukmana (2018), stres biasanya diawali dengan perasaan jengkel dan marah, sulit berkonsentrasi, sulit tidur, sering mengalami jantung berdebar-debar saat keadaan cemas, raa sakit kepala sehingga selera makan berkurang. Apabila stres dibiarkan maka tubuh akan terbiasa menyesuaikan diri dan bertahan hidup dalam tekanan. Kondisiini menyebabkan perubahan fatologis dalam jaringan organ tubuh manusia malalui saraf otonom. Sebagai akibatnya akan timbul penyakit adaptasi yang berupa gastritis. Oleh karena itu, penderita harus lebih rileks dan menghindari stres, karena stres dapat memproduksi asam lambung yang berlebihan.

\section{KESIMPULAN}

Berdasarkan hasil analisa dan pembahasan terhadap hasil penelitian maka dapat disimpulkan bahwa :

1. adanya hubungan faktor kebiasaan makan dan kebiasaan minum kopi dengan kejadian gastritis pada pasien yang berobat di Puskesmas Lak-Lak Kecamatan Ketambe Kabupaten Aceh Tenggara Tahun 2019 dimana diperoleh nilai $p=0,035$ dan faktor kebiasaan minum kopi diperoleh nilai $p=0,036$.

2. Sementara faktor kebiasaan merokok, kebiasaan konsumsi alkohol dan stres tidak berhubungan dengan kejadian gastritis pada pasien yang berobat di Puskesmas Lak-Lak Kecamatan Ketambe Kabupaten Aceh Tenggara Tahun 2019 karena faktor kebiasaan merokok diperoleh nilai $p=0,651$, faktor kebiasaan konsumsi alkohol nilai $p=0,756$ dan faktor stres diperoleh nilai $p=0,139$.

\section{SARAN}

Agar tenaga kesehatan di lingkup puskesmas Lak-Lak Kecamatan Ketambe Kabupaten Aceh Tenggara memberikan penyuluhan kepada masyarakat secara berkala tentang faktor-faktor penyebab kejadian 
Received: 02 Oktober 2019 :: Accepted: 08 Oktober 2019:: Published: 31 Oktober 2019

gastritis. Selain itu, perlu dilakukan kajian lebih lanjut tentang solusi pencegahan dan penanganan penyakit gastritis.

\section{DAFTAR PUSTAKA}

Arikah \& L. Muniroh. (2015). RIWAYAT MAKANAN YANG MENINGKATKAN ASAM LAMBUNG SEBAGAI FAKTOR RISIKO GASTRITIS. JURNAL GIZI INDONESIA, (JGI). Vol, 38(1), 920.

Brunner \& Suddarth. (2013). Buku Ajar Keperawatan Medikal Bedah Edisi 8 Volume 2. EGC, Jakarta.

Benita, N.R. (2012). PENGARUH PENYULUHAN TERHADAP TINGKAT PENGETAHUAN KESEHATAN REPRODUKSI PADA REMAJA SISWA SMP KRISTEN GERGAJI. Karya Tulis Ilmiah. Program Pendidikan Sarjana Kedokteran. Fakultas Kedokteran. Universitas Diponegoro.

Lumiwu, F. O.R. Pinontoan \& B.T. Rataq. (2015). Faktor-Faktor Yang Berhubungan Dengan Kejadian Gastritis Di Wilayah Kerja Puskesmas Talawid Kecamatan Siau Barat Selatan Kabupaten Sitaro Tahun 2015. Skripsi. Fakultas Kesehatan Masyarakat Universitas Sam Ratulangi Manado.

Misnadiarly. (2009). Mengenal Penyakit Organ Cerna ; Gastritis (Dyspepsia atau Maag). Pustaka Populer OBDA, Jakarta.

Mardiansyah, M. (2019). KUALITAS PELAYANAN PUSKESMAS TERHADAP PENGGUNA PROGRAM BPJS KESEHATAN DI PUSKESMAS PAGURAWAN. JURNAL KESEHATAN MASYARAKAT \& GIZI (JKG), 1(2), $16-$

20.https://doi.org/10.35451/jkg.v $1 \mathrm{i} 2.115$

Megawati, A. D. \& H. Nosi. (2014). Beberapa Faktor Yang Berhubungan Dengan Kejadian Gastritis Pada Pasien Yang Di Rawat Di RSUD Labuang Baji Makassar. Jurnal IImiah Kesehata Diagnosis, (JKD). Vol, 4(6), 709715.
Putri, R.S.M., H. Agustin \& Wulansari. (2010). Hubungan Pola Makan Dengan Timbulnya Gastritis Pada Pasien Di Universitas Muhammadiyah Malang Unit Medical Center (UMC). JURNAL KEPERAWATAN, (JKEP). VOL , 1(2)., 156-164.

Rukmana, L.N. (2018). Faktor-Faktor Yang Mempengaruhi Kekambuhan Gastritis Di Sman 1 Ngaglik. Skripsi. Program Studi IImu Keperawatan Fakultas IImu Kesehatan. Universitas Aisyiyah Yogyakarta.

Sirait, R., \& Lubis, I. (2018). Pengaruh Kepatuhan dan Motivasi Penderita TB Paru Terhadap Tingkat Kesembuhan Pengobatan di Puskesmas Tanjung Morawa Kabupaten Deli Serdang Tahun 2017. Jurnal kesehatan masyarakat \& gizi $(j k g), 1(1), 43-$ 49.https://doi.org/10.35451/jkg.v $1 \mathrm{i} 1.85$.

Suarniati. (2013). Hubungan antara konsumsi cafein dengan kejadian gastritis di rsu. Islam faisal maksassar. Jurnal ilmiah kesehatan diagnosis, (JIKD), Vol, 3(2). http://fmipa.umri.ac.id/wpcontent/uploads/2016/06/DienFadilah-Gastritis.

Tussakinah, W., MASRUL, \& I.R. BURHAN. (2018). Hubungan Pola Makan Dan Tingkat Stres Terhadap Kekambuhan Gastritis Di Wilayah Kerja Puskesmas Tarok Kota Payakumbuh Tahun 2017. Jurnal Kesehatan Andalas, (JKA). Vol, 7(2).https://doi.org/10.25077/jka. v7.i2.p217-225.2018. 